\title{
AN INVESTIGATION OF THE GENERATION AND MANAGEMENT OF CONSTRUCTION AND DEMOLITION WASTE IN VIETNAM
}

\author{
Ha Tan Nghiem ', Quang Minh Phan ${ }^{1}$, Ken Kawamoto ${ }^{2}$, Kim Tuan Ngo ${ }^{1}$, Hoang Giang \\ Nguyen ${ }^{1, *}$, Tien Dung Nguyen ${ }^{1}$, Yugo Isobe ${ }^{3}$ and Mikio Kawasaki ${ }^{3}$
}

${ }^{1}$ National University of Civil Engineering, 55 Giai Phong Rd., Hanoi, Vietnam

${ }^{2}$ Graduate School of Science and Engineering, Saitama University, 225 Shimo-okubo Sakura-ku Saitama, Japan

${ }^{3}$ Center for Environmental Science in Saitama, 914 Kamitanadare, Kazo, Saitama Prefecture 347-0115, Japan

Article Info:

Received:

21 November 2019

Revised:

18 March 2020

Accepted:

9 April 2020

Available online:

7 September 2020

Keywords:

Area-based calculation

Construction and demolition waste

management

Generation rate

Vietnam

\section{ABSTRACT}

As a developing country in the context of globalization, Vietnam is experiencing a boom in its economy, characterized by a rapid rate of urbanization nationwide. Together with its benefits, this process also puts pressure on the environment, among which the increasing generation of construction and demolition waste (CDW) is an urgent issue. In this study, the authors conducted an in-depth investigation of various aspects in the generation and management of CDW in Vietnam. Firstly, part of the overall picture of CDW management in Vietnam was revealed in detail from the perspective of demolition contractors, one of the important stakeholders in the field. Their insights provide valuable information on current situation, practice, and attitude towards CDW recycling. Secondly, this paper reports the generation rate of different categories of materials from demolition sites of building structures in $\mathrm{Ha}$ noi, Vietnam, with the main focus on crushed concrete and crushed brick (CC-CB) and steel as they make up the majority of the generated waste. In order to achieve two mentioned goals, close contact was constantly kept with a key collaborator - a renowned demolition contractor in Hanoi throughout the investigation. The collaborator provided proper introduction to enable interviews with various other contractors, together with information of buildings being dismantled.

\section{INTRODUCTION}

According to official statistics, the total amount of CDW generated in major cities in Vietnam is approximately 1.46 to 1.92 million tons per year (MONRE, 2011). Together with the low recycling rate of only $1 \%$ to $2 \%$ (MONRE, 2011), this enormous and increasing source of solid waste is also ill-managed due to the lack of legislation, awareness, technology, and various other reasons. In various other countries, CDW has been studied and proven to be an effective substitute for natural materials. For instance, the first systematized research on CDW as aggregate for concrete was conducted in Germany soon after World War II (Nixon, 1978). Should the main content of CDW (brick, concrete, metal, wood, etc.) be reused and recycled, it would not only be economical but also reduce pressure on the urban environment. The status of the annual CDW generation and treatment in some advanced countries is summarized in Table 1 to compare with the situation in Vietnam.

Various studies converge on the fact that CDW poses as one of the major concerns to the environment even in developed countries due to its enormous percentage in the total amount of solid waste. In the United States, 534 million tons of CDW were generated in 2014 (EPA, 2016) which made up $67.4 \%$ of solid waste. Respective numbers in the EU-28 in 2016 were reported to be 924 million tons and $36.4 \%$ (Eurostat, 2018); whereas in China in 2013 were 2.36 billion tons and $30-40 \%$ (Zheng et al, 2017; Huang et al, 2018). The topic of management of CDW has been intensively studied in many countries. It is possible to mention recent papers in European countries such as Germany (Hiete et al, 2011), Norwey (Bersgdal et al, 2007), Portugal (de Melo and Goncalves, 2011; Coelho and de Brito, 2012), Spain (Coronado et al, 2011; Mercante et al, 2012; Saez et al, 2013), Greece (Fatta et al, 2003; Banias et al, 2010); in Asian countries and regions such as China (Hu et al, 2010; Lu et al, 2011; Xiao et al, 2012; Jin et al, 2017), Hong Kong (Deng et al, 2008; Tam, 2011), Taiwan (Hsiao et al, 2002), Kuwait (Kartam et al, 2004), Malaysia (Hussin et al, 2013), Thailand (Koforowola and Gheewala, 2009; Luangcharoenrat et al, 2019); as well as in many others around the world. All countries strongly encourage recycling CDW as one of the sustainable solutions and some have achieved high recycling rate as summarized in Table 1. 
TABLE 1: Estimated amounts of CDW generated and recycled percentage in some countries including Vietnam.

\begin{tabular}{|c|c|c|c|c|c|}
\hline $\mathbf{S} / \mathbf{N}$ & Country & Year of data & $\begin{array}{l}\text { Amount of CDW } \\
\text { (Million tons/year) }\end{array}$ & $\begin{array}{l}\text { Recycled percentage } \\
(\%)\end{array}$ & Source \\
\hline 1 & Japan & 2012 & 72.69 & 96 & MLIT (2017) \\
\hline 2 & Korea & 2009 & 67 & 36 & Bansal and Singh (2014) \\
\hline 3 & Germany & 2012 & 89 & 85 & Deloitte (2017) \\
\hline 4 & France & 2012 & 76 & 93 & Deloitte (2017) \\
\hline 5 & United Kingdom & 2012 & 47 & 70 & Deloitte (2017) \\
\hline 6 & Italy & 2012 & 40 & 79 & Deloitte (2017) \\
\hline 7 & Spain & 2012 & 28 & 98 & Deloitte (2017) \\
\hline 8 & Netherlands & 2012 & 26 & 83 & Deloitte (2017) \\
\hline 9 & Vietnam & 2009 & $1.5-1.9$ & $1-2$ & MONRE (2011) \\
\hline
\end{tabular}

The CDW situation in Vietnam is gradually getting worse with all existing research agree on an overall rising trend of the amount generated. Lockrey et al (2016) projected the total amount of CDW generated in 2020 in Vietnam to be 6.3 million tons, and in 2025 to be 11 million tons. Inadequate management of CDW is causing Vietnam three major problems: illegal dumping, hazardous waste, and depletion of natural resources (Nguyen et al, 2018). In recent years, the Vietnamese government has enforced strong measures through the Ministry of Construction and Ministry of Natural Resources and Environment in order to realize the 'National Strategy for Management of Solid Waste up to 2025, and Vision towards 2050.' The mentioned strategy, issued by the Prime Minister, pursuant to Decision No. 2149/QD-TTg on 17 December 2009 states: "In 2025, the aim is recovering $90 \%$ of the amount of CDW, and recycling $60 \%$ of such amount".

Literature review reveals that studies on CDW in Vietnam are limited in number, it is even possible to state that this is one of the new frontiers of research in the country. Statistics of CDW are available in periodic Reports on National Environment by the Ministry of Natural Resources and Environment (MONRE), and serve as good references for researchers. Naturally, CDW is grouped in the solid waste category, and sometimes is considered hazardous. Nguyen (2009) briefly touched CDW among the studied hazardous industrial waste. By summarizing existing knowledge, the paper presented an overall view of the situation in Vietnam including practices and regulations, and proposed a number of future directions for treating this general type of waste. Tong et al (2013) presented the experience of reusing and recycling CDW as recycled aggregates for concrete in the world, and suggested employing this method for CDW in Vietnam. The authors compared studies of recycled aggregate concrete in various countries, and summarized data of important mechanical properties such as strengths, elastic modulus, and water absorption to give insights on its viability as a construction material in Vietnam. Also targeting the prospect of reusing and recycling CDW, Lockrey et al (2016) conducted a careful assessment on opportunities and challenges. The authors employed known data to project the total CDW generated in Vietnam and in Hanoi; a number of stakeholders (policy makers, Urban Environment Company, contractors) are then interviewed to analyze the CDW flow in Hanoi, current constraints to recycling CDW, and the stakeholders' opinion on the economic attractiveness of CDW. A thorough study by Nguyen et al (2018) presented an overall view of CDW management situation in Vietnam. Within the paper, a number of topics were discussed such as: CDW generation countrywide and trend, responsible stakeholders and current practice in managing CDW, legislations and regulations on CDW, together with recommendations for sound CDW management in Vietnam. It is clearly observed that most existing literature mainly stopped at overview level, with the exception of Lockrey et al who provided some field data through interviews. An in-depth view on the complicated state of CDW management in Vietnam is rather lacking.

This paper intends to shed further light on such situation by attempting to achieve two objectives. First, to gain an overall understanding of demolition contractors in the two largest cities - Hanoi and Ho Chi Minh City (HCMC). Being one of the important stakeholders in the CDW management process, they can reveal the practices, awareness, and feasibility of CDW recycling in Vietnam. Second, to come up with an estimation of waste generation rate from demolition of structures in Vietnam (case study in Hanoi). This value can effectively aid in future projection of demolition waste by relating it to construction rate. An important clarification must be made between "construction waste" (CW - generated from new constructions) and "demolition waste" (DW - from dismantling or renovating old constructions) in the context of Vietnam in order to specify the scope of this study. It is later found out through interviews that most demolition contractors also operate in the field of construction, and many of them accept to transport both CW (hired by construction contractors) and DW (from their own demolition sites) since they possess the necessary equipment. Hence, the first objective of this study targets both CW and DW. The second objective, however, only targets DW from dismantling buildings in Hanoi.

\section{RESEARCH METHODOLOGY}

It was fully acknowledged that to sketch a clear picture of CDW situation in the two largest cities of Vietnam, the party that directly involves in the process of handling CDW - namely demolition contractors - must be reached out for. This approach was also maintained in the obtain- 
ment of building structures to be surveyed in the quantification of DW. To attain the two intended targets specified in previous section, the authors made a complete list of demolition contractors in Hanoi and HCMC, and kept close contact with them throughout the course of the study. Field methods such as interview or survey were then employed to collect data from such party. One particular contractor in Hanoi was also identified as key collaborator and introduced the authors to survey various demolition sites. This step was the most crucial to the success of this study since the CDW business in Vietnam in general, and in Hanoi in particular, is rather complicated. Normally, it is challenging to gain access to demolition sites since all contractors are extremely cautious. Only with the introduction of a renowned contractor were the authors allowed to conduct site visits and ask further data and information.

\subsection{Interview methodology}

Face-to-face interviews were conducted with a total of 46 demolition contractors currently operating in the two largest cities in Vietnam, Hanoi and HCMC. There were 29 contractors in Hanoi and 17 in HCMC who agreed to be interviewed, the number of employees among which ranged from several dozen to approximately two hundred. The companies participate in a wide range of activities as will be shown in the subsequent results and discussion part of this paper; however, they are directly involved in demolishing structures, and/or transporting CDW, and/or collecting and treating CDW.

The contractors were first contacted by email and telephone to set up meetings. Interviews in Hanoi were carried out continuously from March 2018 through January 2019; while those in HCMC were conducted in December 2018. Because of the complicated nature of the demolition business in Vietnam, an agreement was reached with the interviewees, in which the two basic codes of conduct are:

- Results collected in the interview is to be used for research purposes only; and

- Identities of interviewees are kept confidential.
Therefore, interviewees are identified by a code number. There is no association with the code number and the sequence of appearance of contractors in the data statistics.

The set of interview questions were designed to target three main areas of information:

- Basic information on contractors: number of employees, fields of operation, experience in the demolition business, and average number of demolition contracts per year;

- Awareness of CDW policies in Vietnam; and

- Challenges in implementing compulsory classification of all CDW.

\subsection{Methodology for quantifying CDW}

\subsubsection{Overview of different methods to quantify CDW}

An in-depth and thorough study by Wu et al. (2014) summarized the main groups of methods to quantify CDW as presented in Table 2 .

It is noted that the amount of CDW in groups of methods 2 and 3 can be determined either by performing a quantity survey on as-built drawings, or by requesting it from contractors.

Methods in group 1 have the advantage of being easily visualized and specific; the shortcoming, however, is that they only produce raw data. The second group of methods (GRC) is also the most popular among researchers as it provides CDW generation per unit (whether per capita, or dollar, or square meter) which can be compared, contrasted, and conclusions drawn from. Groups of methods 3,4 , and 5 are relatively modern and require a rather complete database on the building (group 3) or the CDW management system as a whole (groups 4 and 5), which can be challenging to conduct in developing countries such as Vietnam.

\subsubsection{Proposed method of survey}

Considering the real scenario in Vietnam, the authors adopted a combination of the indirect measurement method (SV group) and the area-based calculation method (GRC group). These two methods complement each other well

TABLE 2: Groups of methods to quantify CDW.

\begin{tabular}{|c|c|c|c|}
\hline $\mathbf{S} / \mathbf{N}$ & Group of method & Method & Description \\
\hline \multirow{2}{*}{1} & \multirow{2}{*}{ Site Visit - SV } & Direct measurement & Calculate CDW stockpile by geometry \\
\hline & & Indirect measurement & Record number of transport trucks \\
\hline \multirow{3}{*}{2} & \multirow{3}{*}{ Generation Rate Calculation - GRC } & Per-capita multiplier & $\begin{array}{l}\text { Amount of CDW } \div \text { Population } \\
\text { Unit: } \mathrm{kg} / \text { capita/year }\end{array}$ \\
\hline & & Financial value extrapolation & $\begin{array}{l}\text { Amount of CDW } \div \text { Building value (USD) } \\
\text { Unit: } \mathrm{kg} / \mathrm{USD}\end{array}$ \\
\hline & & Area-based calculation & $\begin{array}{l}\text { Amount of CDW } \div \text { Gross Floor Area }\left(\mathrm{m}^{2}\right) \\
\text { Unit: } \mathrm{kg} / \mathrm{m}^{2}\end{array}$ \\
\hline \multirow[t]{2}{*}{3} & \multirow{2}{*}{ Lifetime Analysis - LA } & Building LA & $\begin{array}{l}\text { Amount of CDW } \div \text { Building age (year) } \\
\text { Unit: } \mathrm{kg} / \text { year }\end{array}$ \\
\hline & & Material LA & $\begin{array}{l}\text { Amount of } \mathrm{CDW} \div \text { Material age (year) } \\
\text { Unit: } \mathrm{kg} / \text { year }\end{array}$ \\
\hline 4 & \multicolumn{2}{|c|}{ Classification System Accumulation - CSA } & $\begin{array}{l}\text { Based on GRC, considering effects of the classi- } \\
\text { fication system }\end{array}$ \\
\hline 5 & \multicolumn{2}{|l|}{ Variables Modelling - VM } & $\begin{array}{l}\text { Model the CDW generation process by a func- } \\
\text { tion of influencing factors }\end{array}$ \\
\hline
\end{tabular}


since they ensure the provision of specific and precise amounts of DW together with comprehensive per square meter data.

In the first step of the procedure, the gross floor area (GFA) of each building was determined by direct measurement on site and verification with information from as-built drawings.

Throughout the demolition process, DW generation was monitored closely. The authors aimed at two main categories of DW, CC-CB and steel. Let the total bulk volume of CC-CB after being crushed to separate reinforcing steel be , this volume is then treated in two ways:

- A major portion is transported to landfills, denoted; and - Another portion is employed as backfilling material on site, denoted.

Volum is determined by recording the number and type of transport trucks, and was used for calculating the generation rate of $C C-C B$ as it is the portion of DW that is discarded, and hence exerts pressure on the environment.

Volume $\mathrm{V} 1$ is converted into mass by multiplying it with the bulk density of CC-CB, (Mália, 2013):

$\mathrm{m}_{\mathrm{CC}-\mathrm{CB}}=\mathrm{V}_{1} \times \rho_{\mathrm{CC}-\mathrm{CB}} \quad[\mathrm{kg}]$

The generation rate of $\mathrm{CC}-\mathrm{CB}$ is then calculated by the following formula:

$\mathrm{G}_{\mathrm{CC}-\mathrm{CB}}=\frac{\mathrm{m}_{\mathrm{CC}-\mathrm{CB}}}{\mathrm{GFA}} \quad\left[\mathrm{kg} / \mathrm{m}^{2}\right]$

Because steel (as well as other metals) is always separated for scrap sale, its mass can be easily obtained. The steel generation rate, therefore, can be determined as follows:

$\mathrm{G}_{\mathrm{S}}=\frac{\mathrm{m}_{\mathrm{S}}}{\mathrm{GFA}} \quad\left[\mathrm{kg} / \mathrm{m}^{2}\right]$

A few photos illustrating the procedure of the survey method are shown in Figure 1.

\section{RESULTS AND DISCUSSION ON CDW MA- NAGEMENT IN VIETNAM}

\subsection{Scale and business of demolition contractors in Vietnam}

Among the 29 demolition contractors in Hanoi, 26 also operate in the field of construction; 15 also transport CDW, among which two companies (Bắc Quân and Tài Lợi) specialize only in transporting CDW. The manpower distribution of these contractors is displayed in Figure 2.

In HCMC, 16 out of 17 demolition contractors simultaneously take on construction works, and seven of them also transport CDW. The manpower distribution of HCMC demolition contractors is shown in Figure 3.

In Vietnam, there are no professional demolition contractors. Interviewees from some companies revealed that they also operate in non-engineering fields such as interior design ( $\mathrm{HN}-25)$, importing beverages $(\mathrm{HN}-11)$, or selling air tickets (HCMC-04).

Compared to Hanoi, the number of demolition contractors in HCMC is significantly less. This was confirmed by interviewee HCMC-10 as he explained: "Small demolition works in HCMC are carried out by individual groups of workers, who do not bother to register a company as Southerners work quite casually".

From the manpower distribution graphs, it is noted as follows:

- The overall trend is that demolition contractors have a low number of engineers (0-7) and many fewer permanent workers than temporary workers (average ratio is $1: 2$ to $1: 4)$;

- The only two companies that have low numbers of temporary workers are Bắc Quân and Tài Lợi, as they specialize in transportation of CDW, and thus hire only permanent truck drivers;

- Companies that also take on construction consultation work (Dr. House, Bắc Việt, and Thăng Long in Hanoi, and ITSCO 68 and Hoàng Gia in HCMC) have more engineers (15-20).

Many of the surveyed contractors have had more than 5 years of experience in the demolition field (28 out of 49 , accounting for $57.14 \%)$. The number of demolition contracts that they take on per year varies widely from 20 to 200 . From the data collected, it can be estimated that there are 1500-2000 buildings (large and small) being demolished in Hanoi annually. In HCMC, there are approximately 900 large works demolished per year. These numbers are also increasing with the urbanization of Vietnam. Hence, it is crucial that CDW management strategies are formulated and implemented to control such pressure on the urban environment.
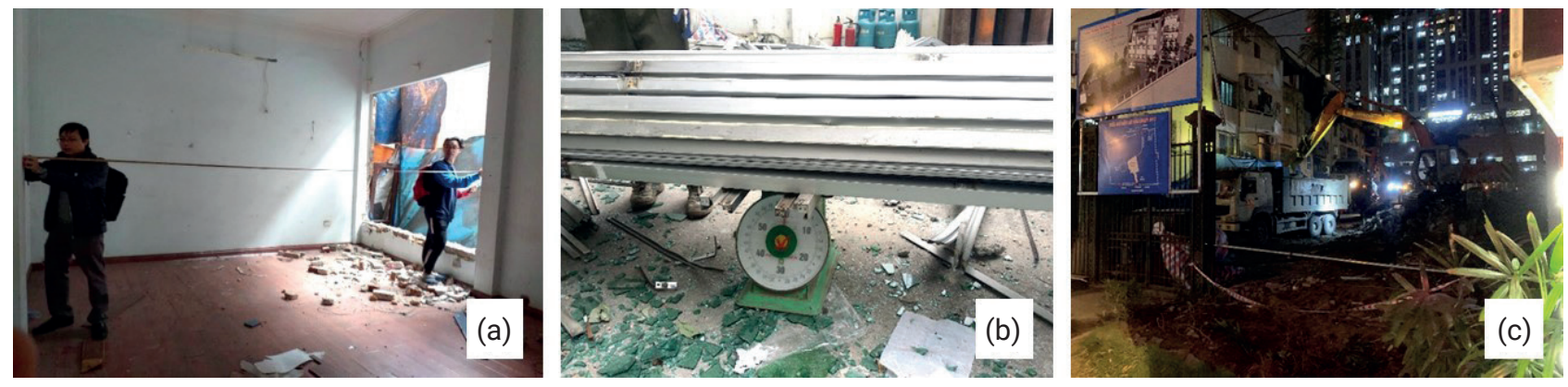

FIGURE 1: Survey of CDW generation (a) Determining GFA; (b) Scrap buyers measuring the amount of aluminum; and (c) Counting the number of CC-CB transport trucks. 


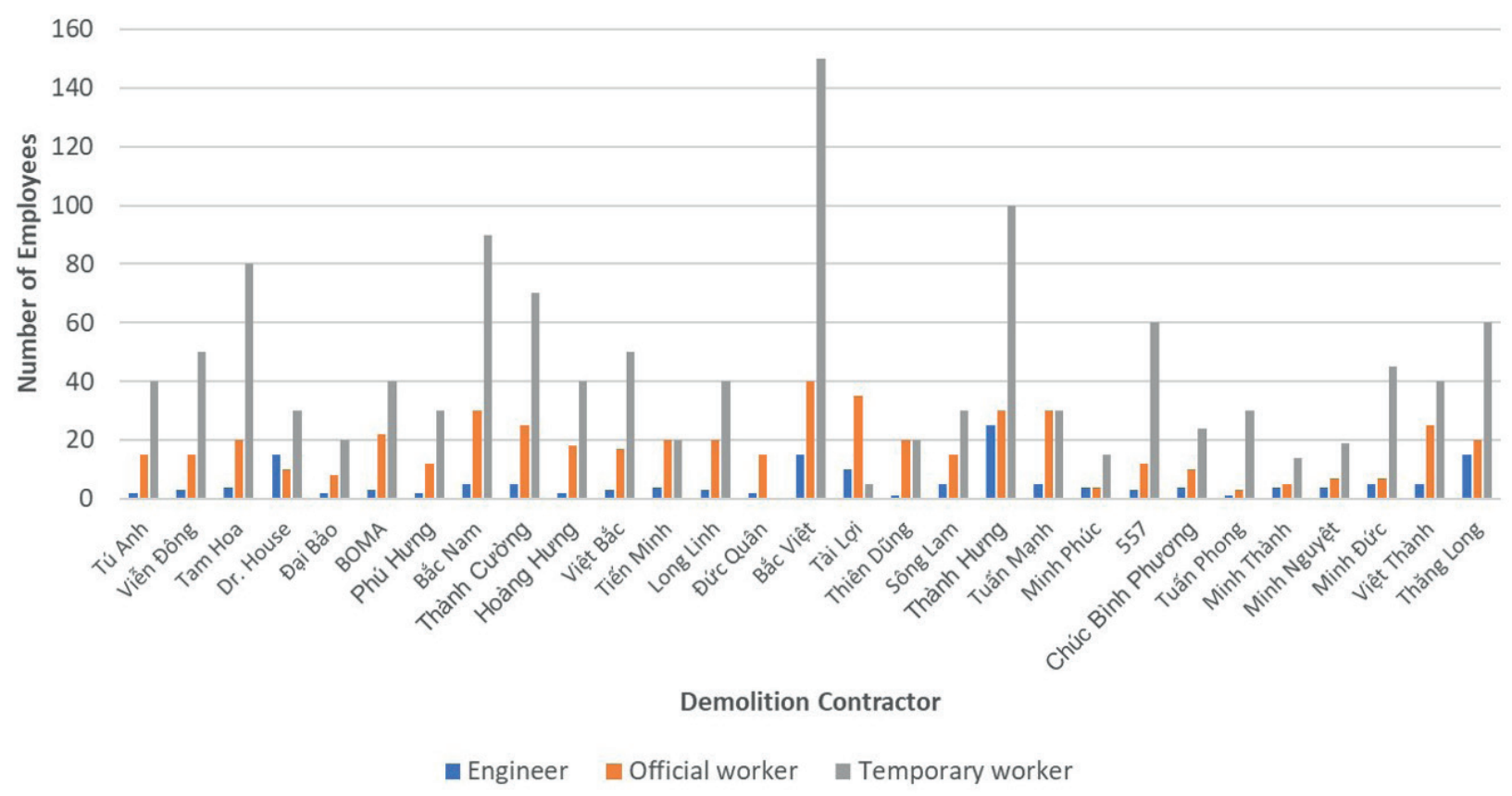

FIGURE 2: Scale of manpower of demolition contractors in Hanoi.

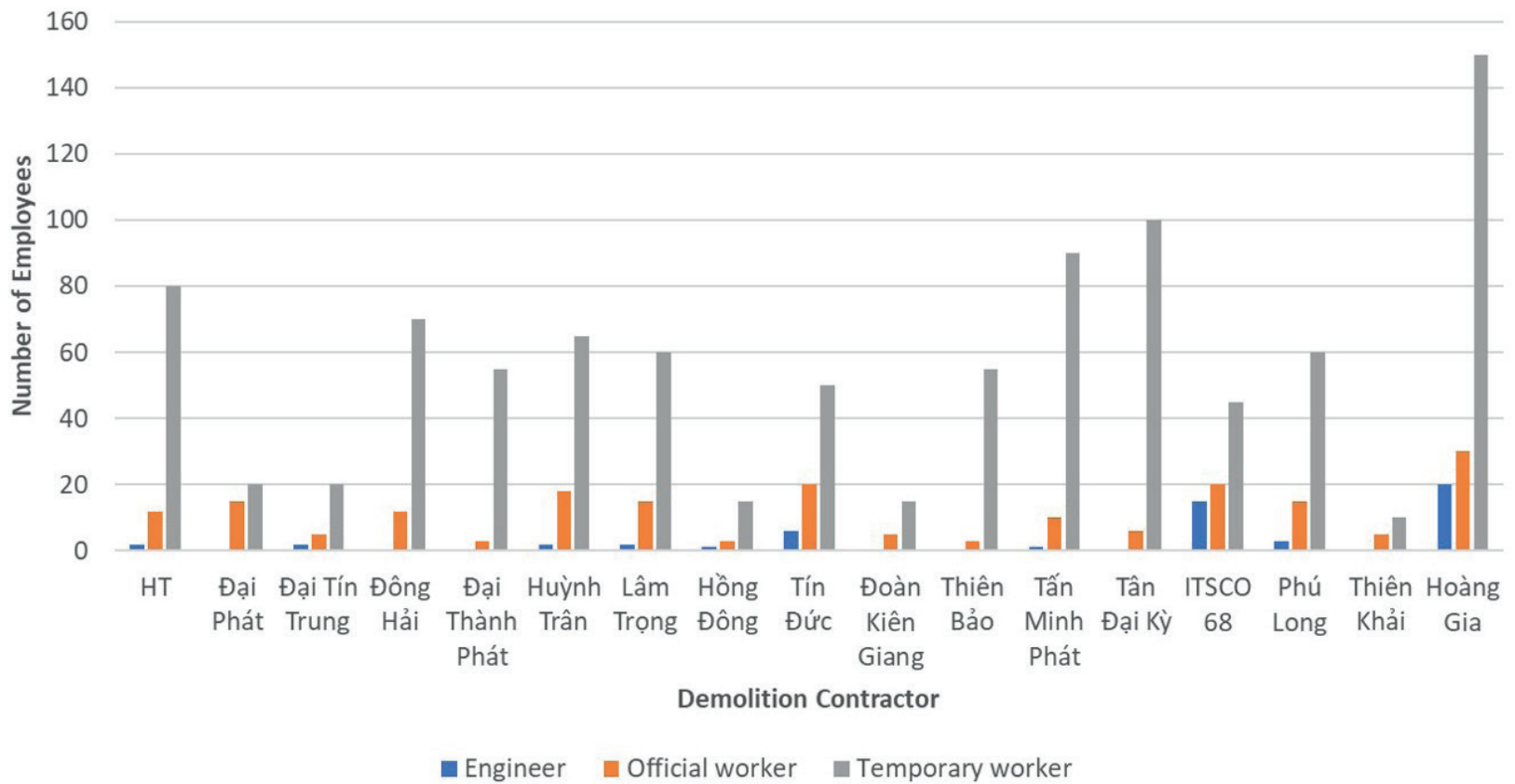

FIGURE 3: Scale of manpower of demolition contractors in Ho Chi Minh City.

\subsection{Awareness of CDW policies}

Currently in Vietnam, there is a set of legal documents regulating solid waste management in general, some of which have attempted to include CDW in their scopes; a summary of these documents can be seen in Table 3 (Nguyen et al., 2018).

Among the items in Table 3, Circular No. 08 directly aims towards CDW, and it is expected to be closely related to the operation of demolition contractors. However, $100 \%$ of interviewees were unaware of any legal document on CDW management, let alone Circular No. 08.
The interviewees were also asked for their opinions on current legislations on CDW in Vietnam; in particular: Are current regulations 1) Easy to follow, 2) Appropriate, 3) Economically efficient, and 4) Necessary. The answers were ranked on five levels, from totally disagree to totally agree. By adopting fuzzy logic theory, linguistic variables were converted into numerical values (Zimmermann, 2001) with the scale as shown in Figure 4 for data analysis.

The results of interviews are presented in Table 4. It is obvious that demolition contractors in Vietnam are neutral, even tend to disagree with the first three items because 
TABLE 3: Vietnamese legal documents relevant to CDW management.

\begin{tabular}{|c|c|c|}
\hline $\mathbf{S} / \mathbf{N}$ & Type and name of document & Year of approval \\
\hline \multicolumn{3}{|c|}{ Lawsuit } \\
\hline 1 & Law on Construction & 2014 \\
\hline 2 & Law on Environmental Protection & 2014 \\
\hline 3 & Law on Urban Planning & 2009 \\
\hline 4 & Law on Public Investment & 2014 \\
\hline \multicolumn{3}{|c|}{ Decree } \\
\hline 5 & Decree No. 59/2007/ND-CP on Solid Waste Management & 2007 \\
\hline 6 & Decree No. 12/2009/ND-CP on Management of Investment Projects on the Construction of Works & 2009 \\
\hline 7 & Decree No. 38/2015/ND-CP on the Management of Waste and Discarded Materials & 2015 \\
\hline 8 & Decree No. 59/2015/ND-CP on Construction Project Management & 2015 \\
\hline \multicolumn{3}{|c|}{ Circular and Joint Circular } \\
\hline 9 & $\begin{array}{l}\text { Circular No. 29/1999/QD-BXD on Promulgating the Regulations of Environmental Protection Applied for the Construc- } \\
\text { tion Sector }\end{array}$ & 1999 \\
\hline 10 & $\begin{array}{l}\text { Circular No. 10/2000/TT-BXD on Guiding the Elaboration of Reports on the Assessment of Environmental Impacts for } \\
\text { Construction Planning Projects }\end{array}$ & 2000 \\
\hline 11 & Circular No. 01/2011/TT-BXD on Guiding the Strategic Environmental Assessment in Construction and Urban Plans & 2011 \\
\hline 12 & Circular No. 08/2017/TT-BXD on Regulation on Construction Solid Waste Management & 2017 \\
\hline 13 & $\begin{array}{l}\text { Joint Circular No. 01/2001/TTLT-BKHCNMTBXD on Guiding the Regulations on Environmental Protection for the Selec- } \\
\text { tion of Location for, and the Construction and Operation of Solid Waste Burial Sites }\end{array}$ & 2001 \\
\hline \multicolumn{3}{|c|}{ Vietnamese Standard } \\
\hline 14 & TCVN 6705: 2009 Ordinary Solid Waste - Classification & 2009 \\
\hline 15 & TCVN 6706: 2009 Hazardous Solid Waste - Classification & 2009 \\
\hline 16 & TCVN 6707: 2009 Prevention and Warning Signs for Hazardous Waste & 2009 \\
\hline 17 & TCVN 6696: 2009 Requirements for Environmental Protection for Sanitary Landfills & 2009 \\
\hline
\end{tabular}

they have not even heard of such regulations. To quote interviewee $\mathrm{HN}-21$ : "Having practiced in this business for over 15 years, the process of demolition is totally dependent on our experience. Previously, up until the early 2000s, Hanoi did not plan a CDW dumping site; only recently there are several sites designated for this purpose, but they are very quickly filled up. We have to maintain an internal network among ourselves to share information of any lake or any idle construction project site that the owner wants to be backfilled or leveled." However, with a high level of consensus, demolition contractors in both cities highly agreed that regulations must be implemented so that CDW is managed and recycled properly.

\subsection{Challenges in implementing compulsory classi- fication of all CDW}

When asked about their interests in CDW recycling, all interviewees were enthusiastic, and acknowledged that it is an inevitable trend. Interviewee HN-05 stated: "We hear that Hanoi used to have a project sponsored by Germany to recycle $C D W$, even a crushing machine was bought to run pilot tests. It is a pity that the project has not yielded any visible results." In HCMC, interviewee HCMC-10 stated: "We have been looking forward to the prospect of CDW recycling, and we will be more than willing to cooperate should such an operation go into action."

Nevertheless, in order to recycle CDW, it must first be sorted into different categories. This extra step may challenge demolition contractors in quite a number of aspects. The authors gave all interviewees a list of nine possible difficulties, both subjective and objective, that they would potentially face when the procedure of classifying all CDW is implemented. Each difficulty was assessed by demolition contractors on five levels, from virtually no challenge to the most challenging. These linguistic variables were then processed with the employment of fuzzy logic with a scale as displayed in Figure 5.

In Table 5, challenges are ranked from 1 (highest numerical value - the most challenging) to 9 (lowest numeri-

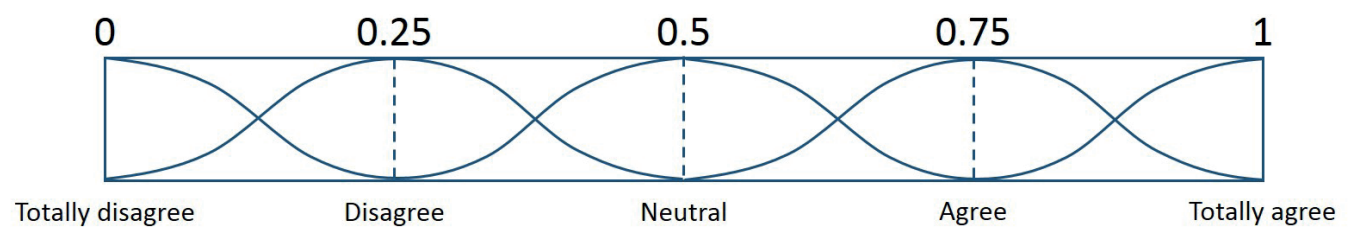

FIGURE 4: Linguistic variables of level of agreement. 
TABLE 4: Opinions of demolition contractors on current legislations on CDW in Vietnam.

\begin{tabular}{|c|c|c|c|c|c|}
\hline \multirow{2}{*}{$\mathbf{S} / \mathbf{N}$} & \multirow{2}{*}{ Inquiry } & \multicolumn{2}{|c|}{ Opinions of demolition contractors in Hanoi } & \multicolumn{2}{|c|}{ Opinions of demolition contractors in $\mathrm{HCMC}$} \\
\hline & & Numerical value & Translation into opinion & Numerical value & Translation into opinion \\
\hline 1 & Ease of following & 0.47 & Neutral & 0.47 & Neutral \\
\hline 2 & Appropriation & 0.52 & Neutral & 0.50 & Neutral \\
\hline 3 & Economic efficiency & 0.35 & Neutral, slightly disagree & 0.35 & Neutral, slightly disagree \\
\hline 4 & Necessity & 0.78 & Agree & 0.81 & Agree \\
\hline
\end{tabular}

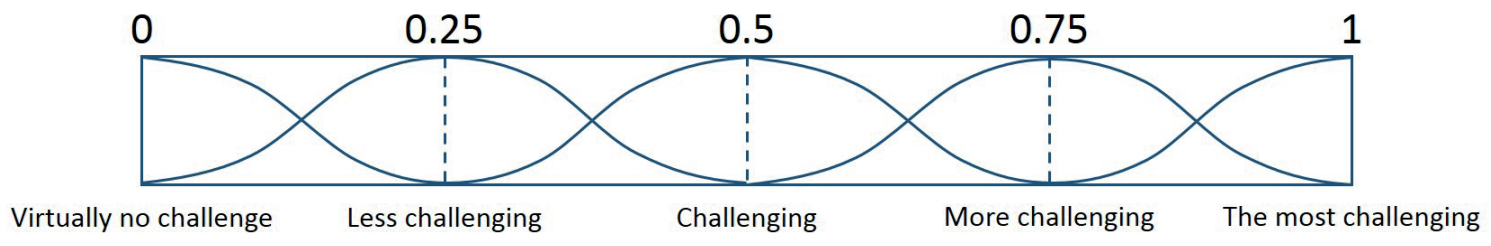

FIGURE 5: Linguistic variables of level of difficulty.

cal value - the least challenging). If there is more than one challenge with the same score, they will share a common rank number. It is observed that the following four challenges are at the top ranking by the assessment of contractors from both cities:

- Cost increase;

- Time consumption;

- Lack of legal guidelines; and

- Lack of post-demolition treatment facilities.

Among these four, the first two are subjective and have a close relationship to each other (cost - time). The other two are objective and need special attention by policy makers as well as researchers to enable such conditions.

\section{RESULTS AND DISCUSSION ON GENERA- TION OF DEMOLITION WASTE, A CASE STU- DY IN HANOI, VIETNAM}

\subsection{General information of surveyed buildings}

Applying the survey method described in the previous section, the authors surveyed DW quantities at a total of nine structures being demolished in Hanoi. The demolition works occured from October 2018 to March 2019. Information on nine buildings is presented in Table 6 including the age, function, and site area. It is necessary to distinguish between site area and GFA, since a building may have multiple floors; moreover, the ground floor area may be smaller than the site area. In this current study, all nine buildings had similar structural features: a reinforced concrete (RC) frame with brick walls.

Each building was designated with a unique ID for ease of reference from this point onwards.

\subsection{Typical flow of demolition work in Hanoi, Viet- nam}

Through daily visits to demolition sites as well as through discussions with site managers, the authors are able to summarize a typical procedure for demolishing buildings, as illustrated in Figure 6. It was confirmed by all site managers that this flow of work is typical and is a combination of manual and machine demolition.

The first phase of demolition involves removal of interior mechanical, electrical, and plumbing (MEP) components,

TABLE 5: Ranking of challenges in implementing compulsory classification of all CDW by demolition contractors in two major cities of Vietnam.

\begin{tabular}{|c|c|c|c|c|c|}
\hline \multirow{2}{*}{$\mathrm{S} / \mathrm{N}$} & \multirow{2}{*}{ Challenge } & \multicolumn{2}{|c|}{ Demolition contractors in Hanoi } & \multicolumn{2}{|c|}{ Demolition contractors in $\mathrm{HCMC}$} \\
\hline & & Numerical value & Ranking & Numerical value & Ranking \\
\hline 1 & Cost increase & 0.60 & 3 & 0.40 & 3 \\
\hline 2 & Manpower shortage & 0.41 & 7 & 0.32 & 5 \\
\hline 3 & Time consumption & 0.56 & 4 & 0.43 & 2 \\
\hline 4 & Lack of skill and technology & 0.42 & 6 & 0.26 & 7 \\
\hline 5 & Lack of machinery & 0.34 & 9 & 0.29 & 6 \\
\hline 6 & Limited site area & 0.41 & 7 & 0.25 & 9 \\
\hline 7 & Lack of legal guidelines & 0.78 & 2 & 0.65 & 1 \\
\hline 8 & $\begin{array}{l}\text { Lack of post-demolition treatment } \\
\text { facility }\end{array}$ & 0.81 & 1 & 0.40 & 3 \\
\hline 9 & Lack of awareness of workers & 0.46 & 5 & 0.26 & 7 \\
\hline
\end{tabular}


TABLE 6: General information on surveyed buildings in Hanoi, Vietnam.

\begin{tabular}{|c|c|c|c|c|c|c|}
\hline $\mathbf{S} / \mathbf{N}$ & $\begin{array}{l}\text { Name of building } \\
\text { (ID) }\end{array}$ & $\begin{array}{l}\text { Year of com- } \\
\text { pletion }\end{array}$ & $\begin{array}{l}\text { Age of building } \\
\text { (years) }\end{array}$ & Building function & $\begin{array}{l}\text { Type of structure } \\
\text { (Number of floors) }\end{array}$ & $\begin{array}{l}\text { Site area } \\
\qquad\left(\mathrm{m}^{2}\right)\end{array}$ \\
\hline 1 & $\begin{array}{l}\text { Thikeco Office } \\
(\text { OFC-01) }\end{array}$ & 1967 & 51 & Office & $\begin{array}{l}\mathrm{RC} \text { frame } \\
(04)\end{array}$ & 846 \\
\hline 2 & $\begin{array}{l}\text { Office at } 177 \text { Trung Kinh } \\
\text { (OFC-02) }\end{array}$ & 2004 & 15 & Office & $\begin{array}{l}\mathrm{RC} \text { frame } \\
(04)\end{array}$ & 1490 \\
\hline 3 & $\begin{array}{l}\text { Office of Vietnam Women's As- } \\
\text { sociation } \\
(\mathrm{OFC}-03)\end{array}$ & 1985 & 33 & Office & $\begin{array}{l}\mathrm{RC} \text { frame } \\
\text { (05) }\end{array}$ & 2583 \\
\hline 4 & $\begin{array}{l}\text { Ngo Sy Lien Secondary School } \\
(\mathrm{SCH}-01)\end{array}$ & 1962 & 56 & Institution & $\begin{array}{l}\mathrm{RC} \text { frame } \\
\text { (05) }\end{array}$ & 2728 \\
\hline 5 & $\begin{array}{l}\text { Apartment Building at } 93 \text { Lang } \mathrm{Ha} \\
\text { (APT-01) }\end{array}$ & 1987 & 33 & Apartments & $\begin{array}{l}\text { RC frame } \\
\text { (05) }\end{array}$ & 5519 \\
\hline 6 & $\begin{array}{l}\text { No. } 1 \text { Truong Chinh } \\
\text { (PVT-01) }\end{array}$ & 2004 & 15 & Private house & $\begin{array}{l}\mathrm{RC} \text { frame } \\
(02+1 / 2)\end{array}$ & 29.76 \\
\hline 7 & $\begin{array}{l}\text { No. } 104 \text { Son Tay } \\
\text { (PVT-02) }\end{array}$ & 2007 & 12 & Private house & $\begin{array}{l}\mathrm{RC} \text { frame } \\
(04)\end{array}$ & 58.9 \\
\hline 8 & $\begin{array}{l}\text { No. } 154 \text { Tan Trieu } \\
\text { (PVT-03) }\end{array}$ & 2001 & 18 & Private house & $\begin{array}{l}\text { RC frame } \\
\text { (03) }\end{array}$ & 263 \\
\hline 9 & $\begin{array}{l}\text { No. } 52-54 \text { Doi Can } \\
\text { (PVT-04) }\end{array}$ & 1989 & 30 & Private house & $\begin{array}{l}\mathrm{RC} \text { frame } \\
\quad(01)\end{array}$ & 318 \\
\hline
\end{tabular}

Source: As-built portfolio, in conjunction with field observation and measurement

interior furniture, doors and windows, and - in some buildings - cladding structures. Most items were salvaged by the previous owner (in case of a private house) or by employees who used to work in that office, as this is a common practice in Vietnam. Cladding may consist of metal components (aluminum or steel) and glass panels that can also be salvaged. Some photos in this phase are presented in Figure 7.

During phase 2, workers use handheld tools to manually demolish slab panels and some structural members (Figure 8). Slab panels are demolished from bottom to top so that materials from upper floors can fall through. Members at the edge are removed first so that this part of the building is separated from adjacent structures, hence min- imizing the effects (Figure 9).

Subsequently, heavy machines are deployed on the site to gradually demolish the rest of the building from top to bottom. During this process, water is sprayed continuously at high pressure from a hose to reduce the amount of dust (Figure 10).

Among DW generated from buildings, reinforcing steel has resale value. Thus, it is always separated from RC slabs, beams, and columns and then cut into smaller pieces using oxyacetylene cutting torches (Figure 11). CC-CB exists in a mixed state, sometimes even with other materials such as wood, plastic, gypsum, etc., and is transported out of the demolition site by trucks. DW transportation occurs in the time frame of 21:00-24:00 daily.
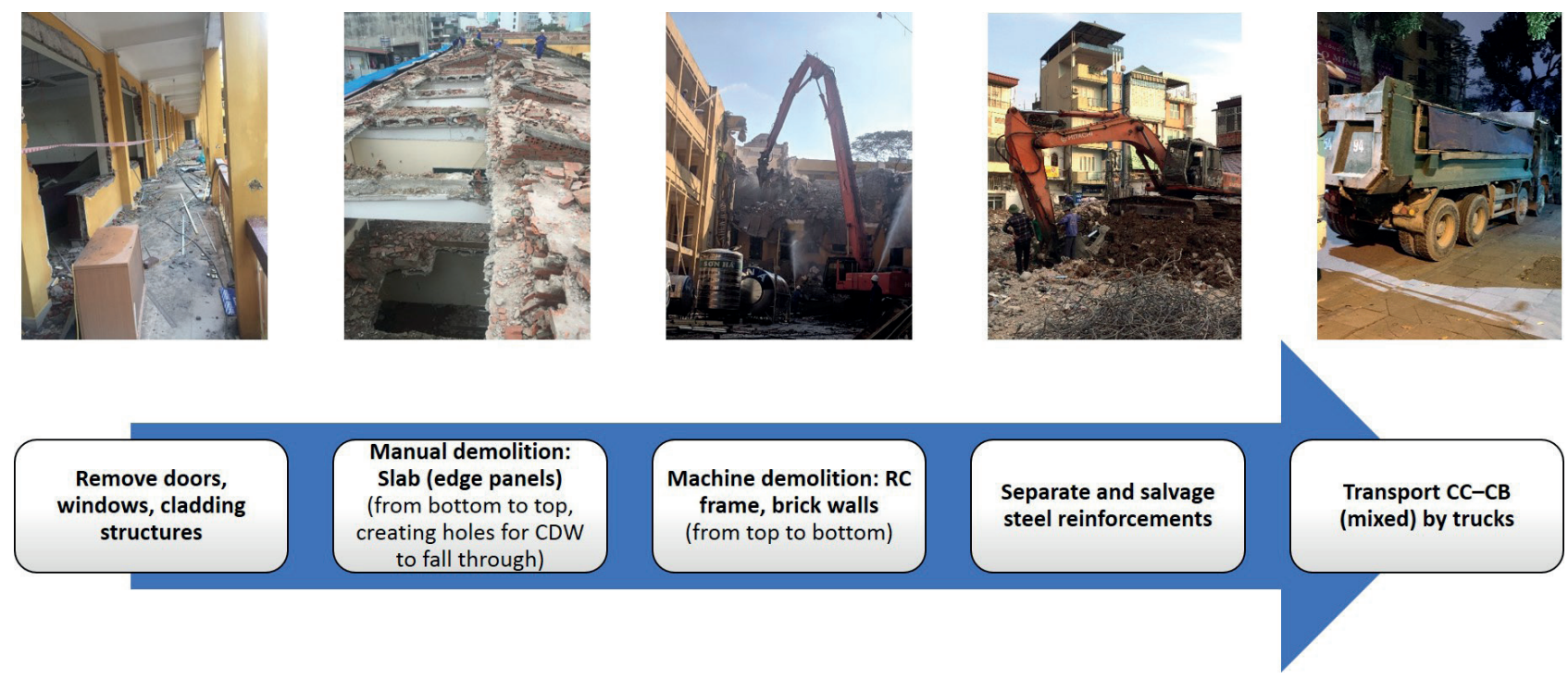

FIGURE 6: Typical flow of demolition work in Hanoi, Vietnam. 

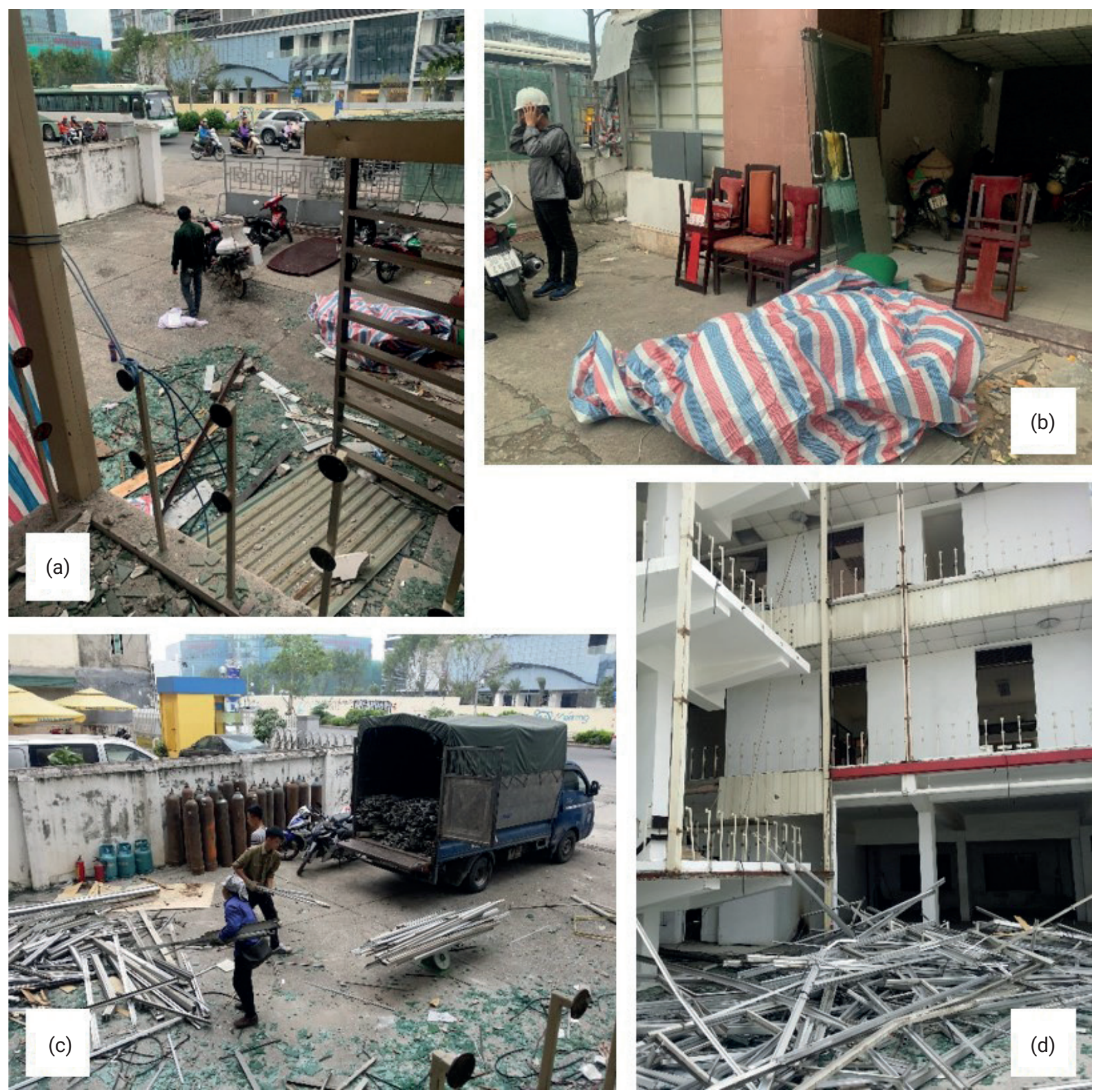

FIGURE 7: Removal of (a) sanitary ware; (b) interior furniture; (c) and (d) aluminum façade at OFC-01.

\subsection{Summary of raw data and economic value of de- molition works}

Data of generated DW by category is summarized in Table 7, including CC-CB, steel (reinforcing steel, as well as other sources), aluminum, glass, and wood.

In Table 7, the economic value (EV) is determined as follows:

- The demolition cost in Vietnam is calculated by volume, and the unit price is $250,000 \mathrm{VND} / \mathrm{m}^{3}$;

- Only the volume of CC-CB is employed for calculating the demolition cost because it makes up the bulk of the DW volume;

- The transportation fee of CC-CB is $40,000 \mathrm{VND} / \mathrm{m}^{3}$.
The economic value of $\mathrm{CC}-\mathrm{CB}$, therefore, is:

$\mathrm{EV}_{\mathrm{CC}-\mathrm{CB}}=\mathrm{V}_{\text {СС-CB}} \times(250,000-40,000) \quad[\mathrm{VND}]$

Steel is sold at $12,000 \mathrm{VND} / \mathrm{kg}$, while aluminum is sold at $30,000 \mathrm{VND} / \mathrm{kg}$. Hence, the economic value of these two types of metal can be calculated by:

$\mathrm{EV}_{\text {metal }}=\mathrm{m}_{\mathrm{S}} \times 12,000+\mathrm{m}_{\mathrm{A}} \times 30,000 \quad[\mathrm{VND}]$

The economic value of the demolition work:

$\mathrm{EV}=\mathrm{EV}_{\mathrm{CC}-\mathrm{CB}}+\mathrm{EV}_{\text {metal }} \quad[\mathrm{VND}]$

\subsection{Generation rate of DW from surveyed buildings}

Applying the formula presented in the previous section, 

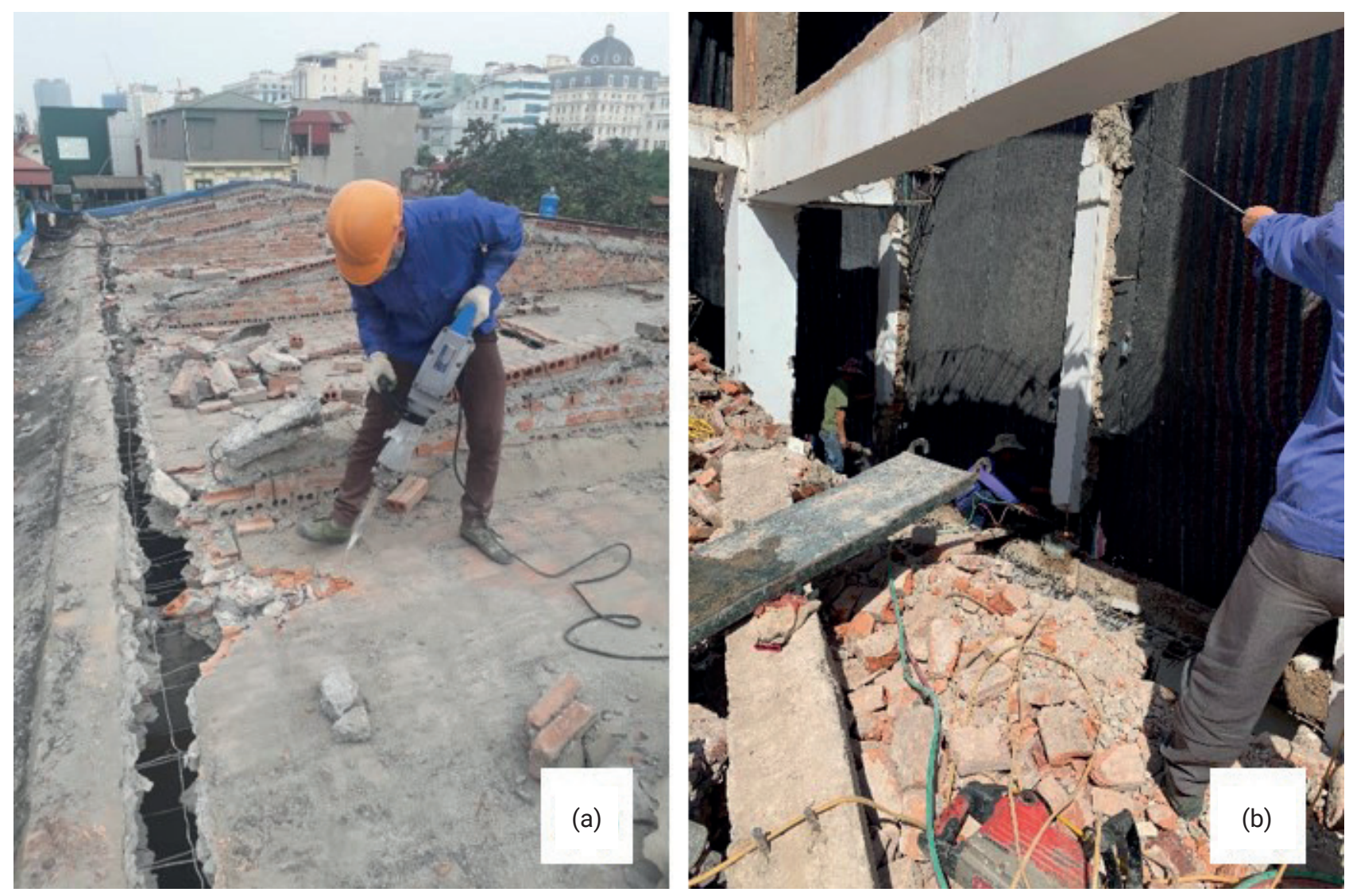

FIGURE 8: (a) Demolition by handheld tool; and (b) A worker manually pulling down an RC column.
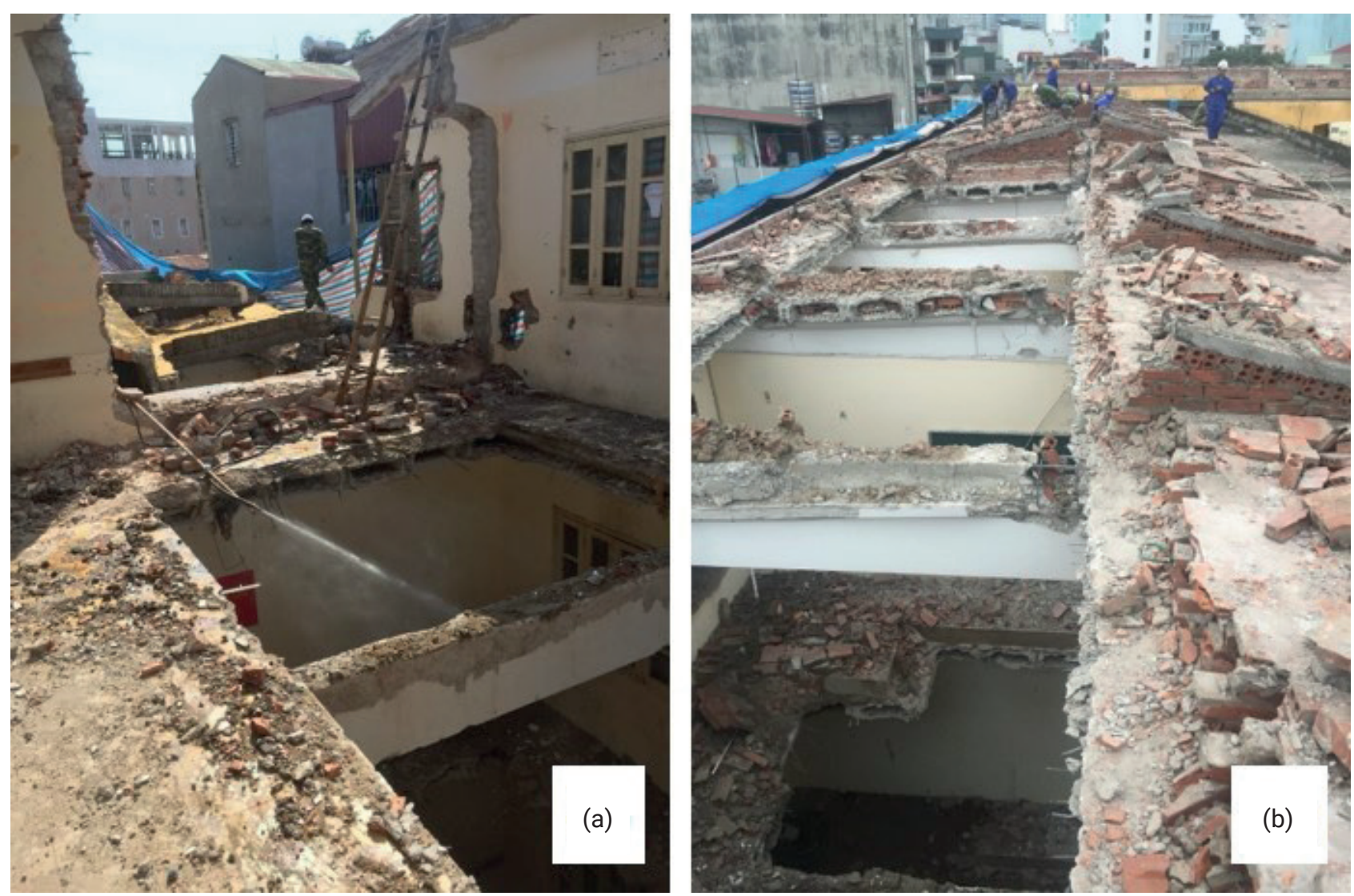

FIGURE 9: (a) Hole for CDW to fall through; and (b) Edge slab panels demolished. 

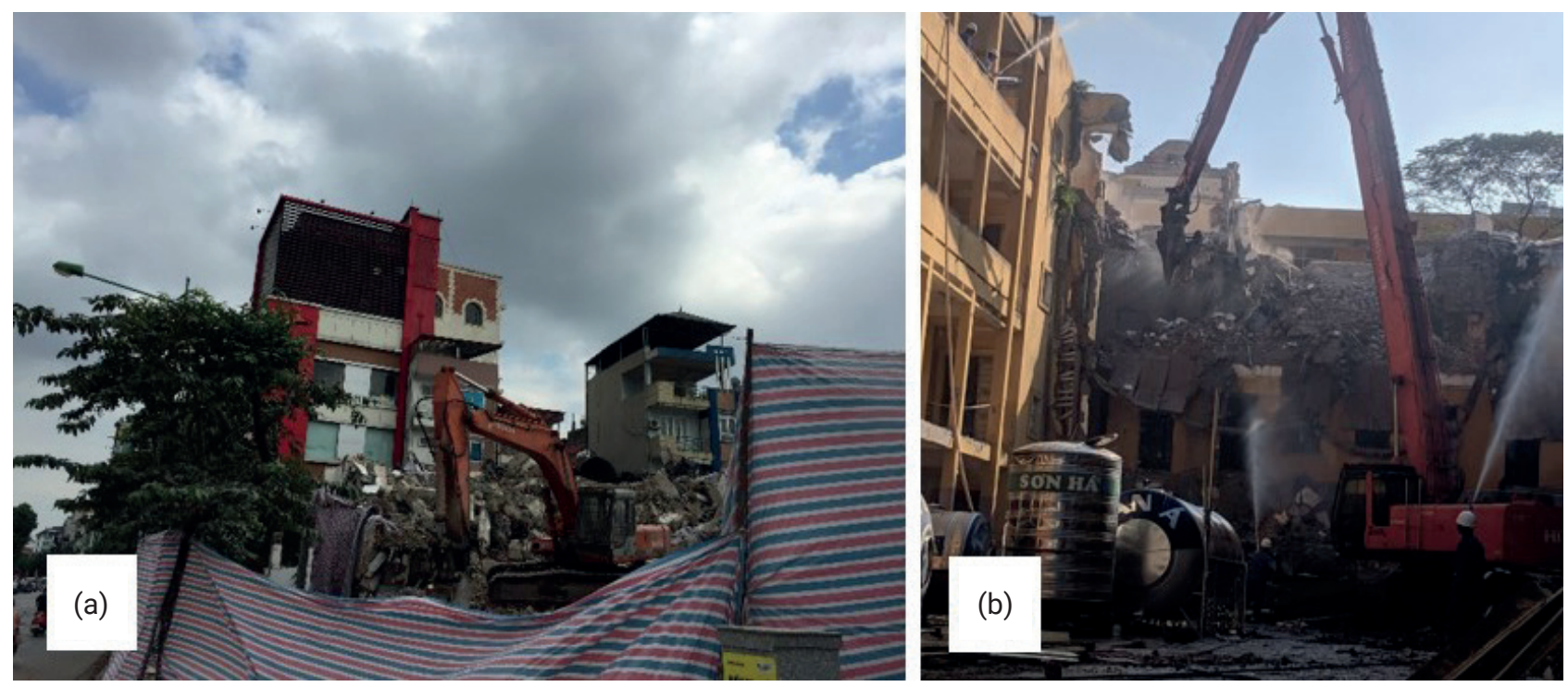

FIGURE 10: Machine demolition at (a) OFC-01; and (b) SCH-01.

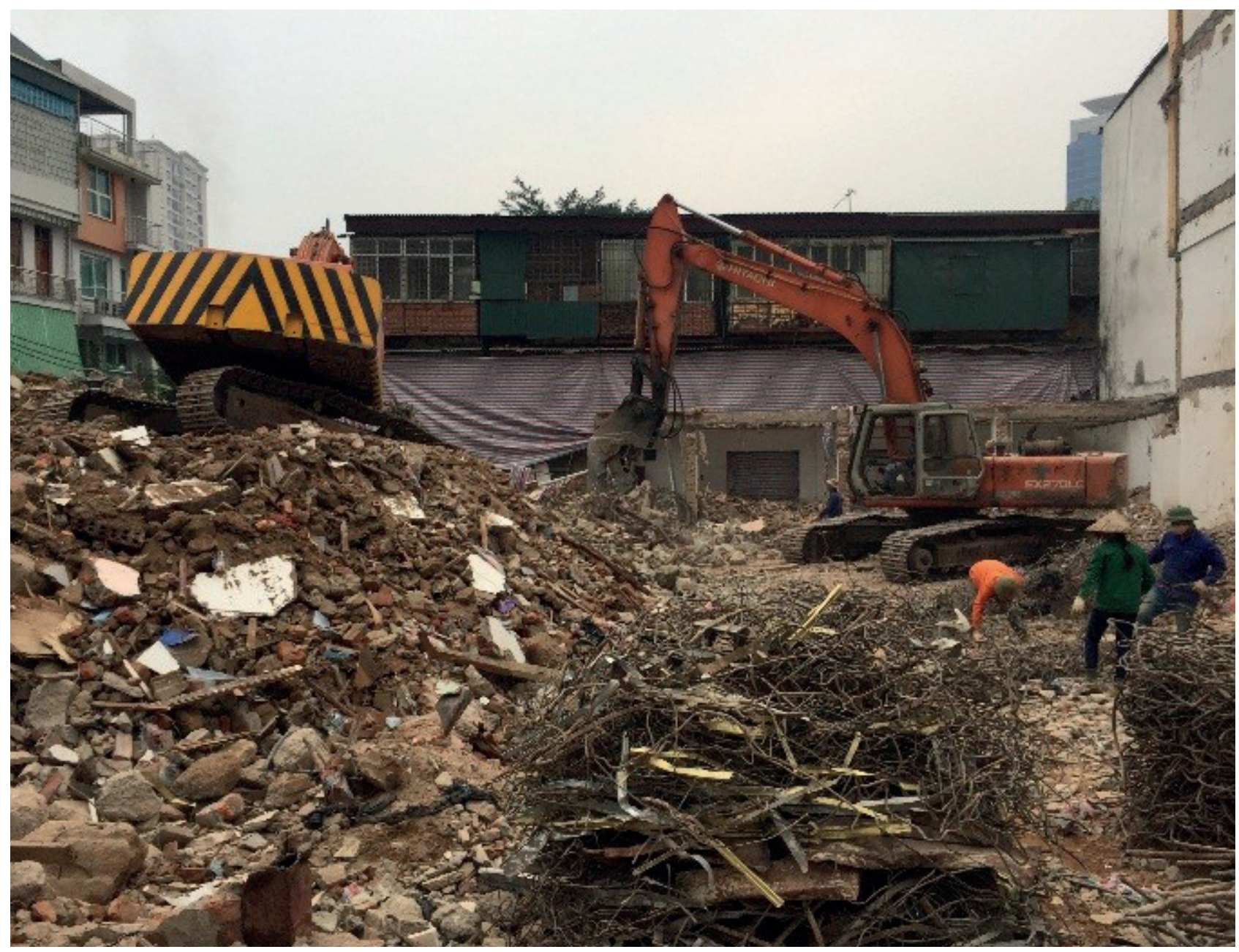

FIGURE 11: Reinforcing steel being separated and recollected.

the authors determined the generation rate of two main types of DW from buildings: 1) CC-CB; and 2) steel. Detailed results are displayed in Table 8 . Generation rates per unit floor area of CC-CB, and of steel are also visualized in the form of column charts in Figure 12 and Figure 13 (respectively). 
TABLE 7: Amount of DW generated from surveyed buildings in Hanoi by category and estimated economic value.

\begin{tabular}{|c|c|c|c|c|c|c|c|c|}
\hline$S / N$ & ID & $\begin{array}{c}\text { Days of } \\
\text { demolition } \\
\text { (days) }\end{array}$ & $\begin{array}{c}\mathrm{CC}-\mathrm{CB} \\
\left(\mathbf{m}^{3}\right)\end{array}$ & $\begin{array}{l}\text { Steel } \\
\text { (ton) }\end{array}$ & $\begin{array}{l}\text { Aluminum } \\
(\mathbf{k g})\end{array}$ & $\begin{array}{c}\text { Glass } \\
\left(\mathrm{m}^{2}\right)\end{array}$ & $\begin{array}{c}\text { Wood } \\
\left(\mathrm{m}^{3}\right)\end{array}$ & $\begin{array}{l}\text { Economic value } \\
\text { (mil. VND) }\end{array}$ \\
\hline 1 & OFC-01 & 23 & 900 & 250 & 1062 & 338 & - & 3220.86 \\
\hline 2 & OFC-02 & 37 & 1260 & 230 & - & - & - & 3024.6 \\
\hline 3 & OFC-03 & 32 & 1500 & 315 & - & - & - & 4095 \\
\hline 4 & $\mathrm{SCH}-01$ & 38 & 4200 & 1450 & - & - & - & 18282 \\
\hline 5 & APT-01 & 70 & 6520 & 1050 & - & - & - & 13969.2 \\
\hline 6 & PVT-01 & 02 & 140 & 0.48 & - & - & - & 35.16 \\
\hline 7 & PVT-02 & 09 & 435 & 1.72 & 72 & 20 & - & 117.51 \\
\hline 8 & PVT-03 & 09 & 920 & 3 & 238 & - & - & 236.34 \\
\hline 9 & PVT-04 & 04 & 500 & 1.1 & 240 & - & 20 & 125.4 \\
\hline
\end{tabular}

Source: Field observation, and interview with informant on-site

For structures that generate aluminum, its generation rate can be calculated by a similar formula:

$\mathrm{G}_{\mathrm{A}}=\frac{\mathrm{m}_{\mathrm{A}}}{\mathrm{GFA}} \quad\left[\mathrm{kg} / \mathrm{m}^{2}\right]$

Subsequently, the generation rate of DW from surveyed buildings can be obtained by summing the three values of $\mathrm{G}_{\mathrm{CC}-\mathrm{CB}}, \mathrm{G}_{\mathrm{S}}$, and $\mathrm{G}_{\mathrm{A}} \cdot \mathrm{G}_{\mathrm{DW}}$ as displayed in Figure 14.

$\mathrm{G}_{\mathrm{DW}}=\mathrm{G}_{\mathrm{CC}-\mathrm{CB}}+\mathrm{G}_{\mathrm{S}}+\mathrm{G}_{\mathrm{A}} \quad\left[\right.$ ton $\left./ \mathrm{m}^{2}\right]$

In terms of the scale of the structure, it is clearly seen that large buildings (GFA of 2000 square meters and above) generate much less CC-CB per unit area than private houses (GFA usually less than 1000 square meters). The reason is that large-scale structures have longer spans, thus reducing the density of $\mathrm{RC}$ frame members. Furthermore, because these buildings function as an office or school, temporary partition walls are often employed in contrast with the permanent brick walls of small houses. However, the steel generation rate of large-scale structures is significantly higher than that of small-scale structures due to the fact that their significance requires a design with much more reinforcing steel content.

It is also noted that APT-01 possesses a CC-CB generation rate higher than that of other large-scale buildings (al- most double) but still much lower than that of small houses. Therefore, it is possible to deduce that building function also affects the DW generation rate.

Considering the effect of building age, one can observe the generation rate of steel from three office buildings. It is obvious that the two recent RC offices were designed with less steel content than the one built in the 1960s (roughly $25 \%$ reduction). This reflects a change in the design standard, and even construction materials (old material versus new).

Finally, the chart of the total DW generation rate closely resembles that of $C$-CB because it is the dominant category of DW in buildings. For offices, varies slightly at around 0.41 tons $/ \mathrm{m}^{2}$ (standard deviation equals 0.026 ), whereas for private houses, fluctuates widely with a mean value of 1.39 tons $/ \mathrm{m}^{2}$ (standard deviation equals 0.211 ).

\section{FURTHER DISCUSSIONS ON FINDINGS OF THE INVESTIGATION}

Through interview, it is revealed that there is no specialized license for demolition work in Vietnam. All contractors who registered license for construction work are also allowed to dismantle structures. Moreover, Vietnamese demolition contractors are currently relying on experience and

TABLE 8: Generation rate of DW from surveyed buildings in Hanoi.

\begin{tabular}{|c|c|c|c|c|c|c|c|}
\hline \multirow[b]{2}{*}{$S / N$} & \multirow[b]{2}{*}{ ID } & \multirow{2}{*}{$\begin{array}{l}\text { GFA } \\
\left(m^{2}\right)\end{array}$} & \multicolumn{2}{|c|}{$\mathrm{CC}-\mathrm{CB}$} & \multirow{2}{*}{$\begin{array}{c}G_{\mathrm{s}} \\
\left(\mathbf{k g} / \mathbf{m}^{2}\right)\end{array}$} & \multirow{2}{*}{$\begin{array}{c}\mathrm{G}_{\mathrm{A}} \\
\left(\mathrm{kg} / \mathrm{m}^{2}\right)\end{array}$} & \multirow{2}{*}{$\begin{array}{c}\mathrm{G}_{\mathrm{DW}} \\
\left.\text { (ton/ } / \mathrm{m}^{2}\right)\end{array}$} \\
\hline & & & $\begin{array}{l}\mathrm{m}_{\mathrm{cc}-\mathrm{cB}} \\
\text { (tons) }\end{array}$ & $\begin{array}{c}G_{\text {сc-св }} \\
\left(\mathbf{k g} / \mathrm{m}^{2}\right)\end{array}$ & & & \\
\hline 1 & OFC-01 & 2392 & 747 & 312.29 & 104.52 & 0.44 & 0.42 \\
\hline 2 & OFC-02 & 2960 & 1045.8 & 353.31 & 77.70 & 0.00 & 0.43 \\
\hline 3 & OFC-03 & 4120 & 1245 & 302.18 & 76.46 & 0.00 & 0.38 \\
\hline 4 & $\mathrm{SCH}-01$ & 9767.5 & 3486 & 356.90 & 148.45 & 0.00 & 0.51 \\
\hline 5 & APT-01 & 9030 & 5411.6 & 599.29 & 116.28 & 0.00 & 0.72 \\
\hline 6 & PVT-01 & 74.4 & 116.2 & 1561.83 & 6.45 & 0.00 & 1.57 \\
\hline 7 & PVT-02 & 235.6 & 361.05 & 1532.47 & 7.30 & 0.31 & 1.54 \\
\hline 8 & PVT-03 & 684 & 763.6 & 1116.37 & 4.39 & 0.35 & 1.12 \\
\hline 9 & PVT-04 & 318 & 415 & 1305.03 & 3.46 & 0.75 & 1.31 \\
\hline
\end{tabular}




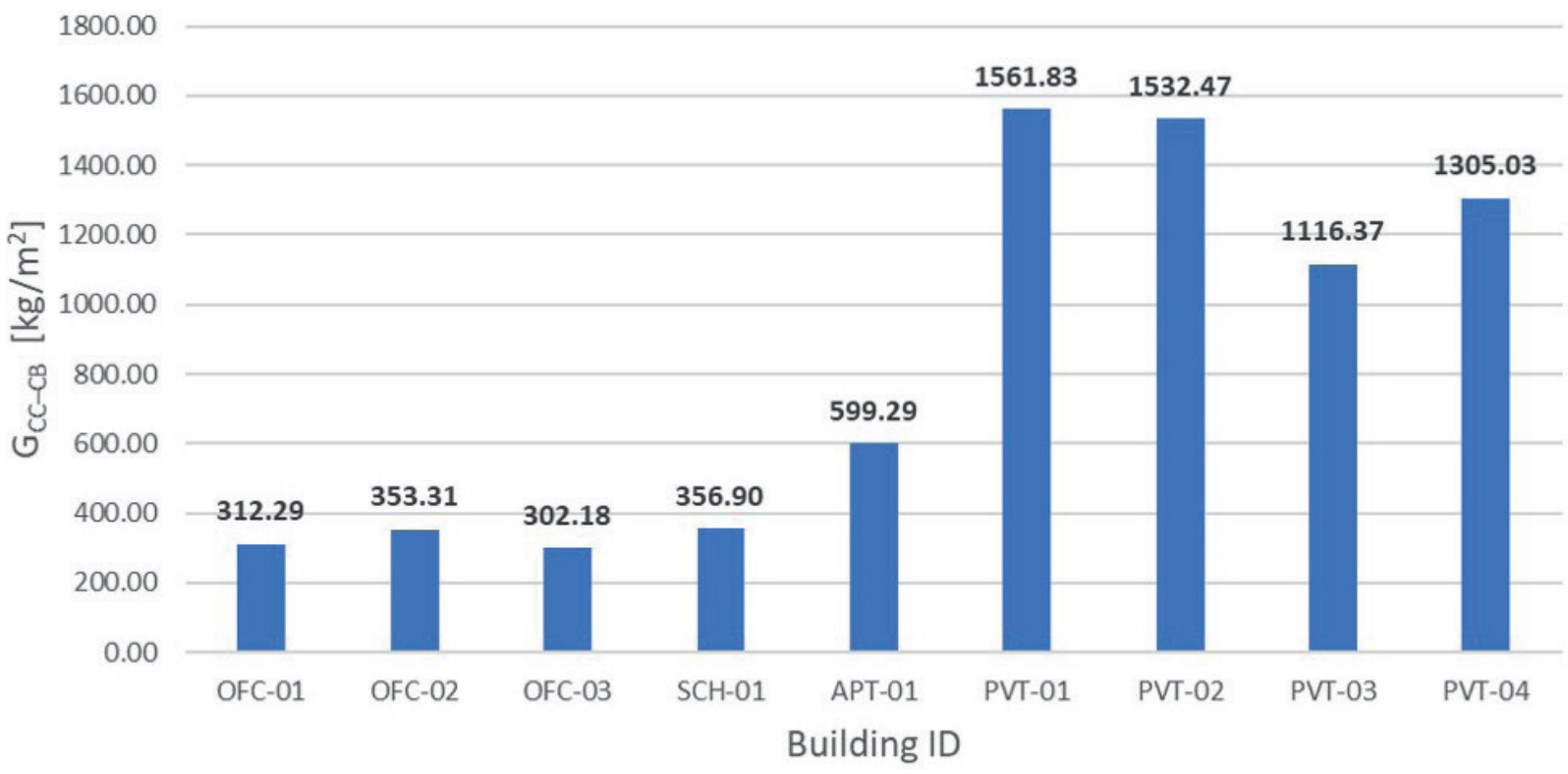

FIGURE 12: Variation of generation rate of CC-CB from surveyed demolition in Hanoi.

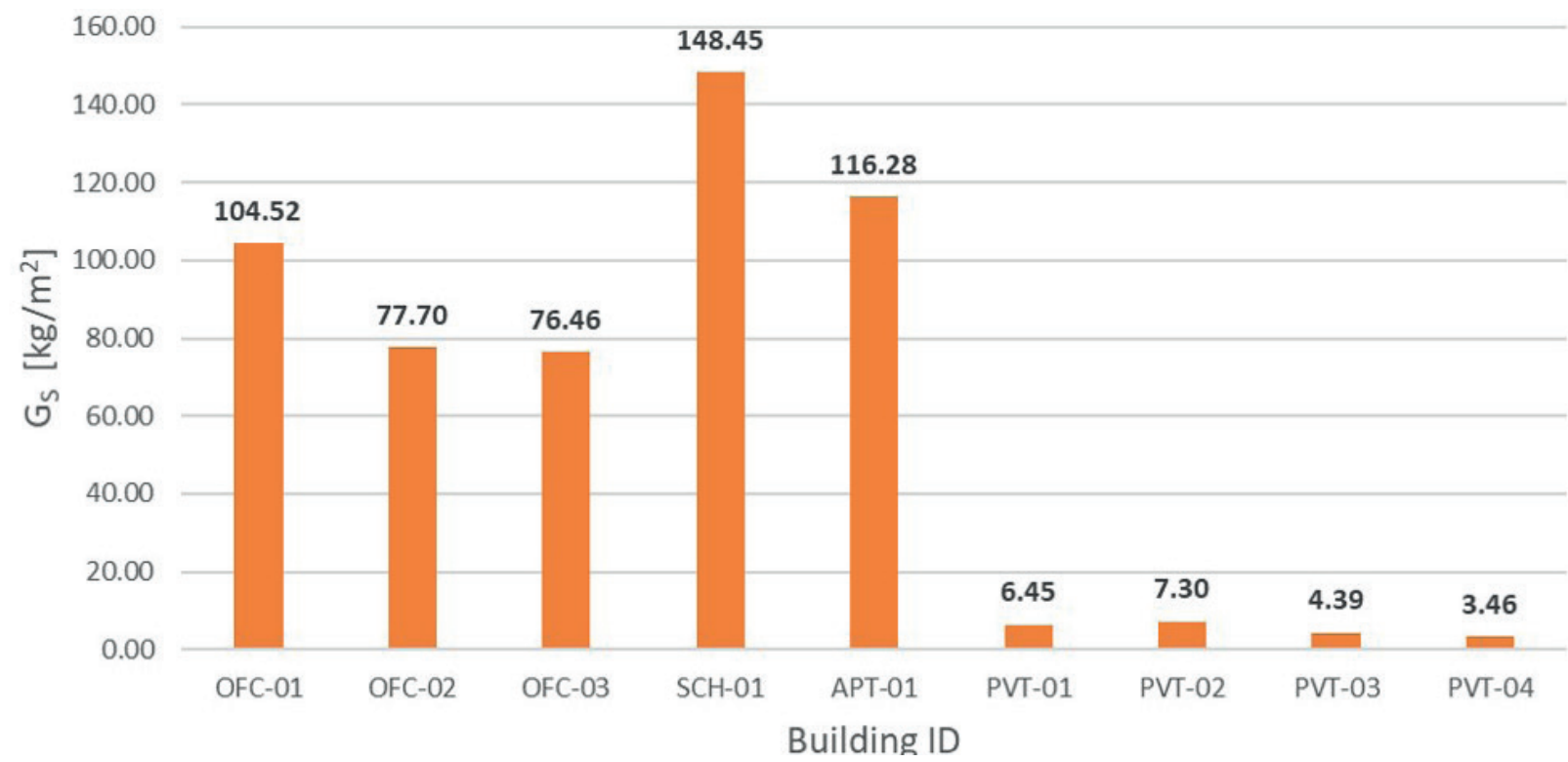

FIGURE 13: Variation of generation rate of steel from surveyed demolition in Hanoi.

personal network to carry out the work rather than proper guidelines and official associations. Being a separate type of work than construction and knowing the practice in countries such as Japan - where demolition contractors need to apply for a specialized license, it is possible to deduce that the management of CDW in Vietnam is unprofessional and lacking. This fact agrees with the low awareness of demolition contractors of current legislation on CDW, as the reason is simple: when operating a business based on experience and personal network, there is no need for legal document.

Many interviewees showed interest in the prospect of reusing and recycling of $\mathrm{CDW}$ (mainly $\mathrm{CC}-\mathrm{CB}$, as metal components are already making profit) and realized the economic attractiveness of this alternative. Currently, for every cubic meter of $\mathrm{CC}-\mathrm{CB}$, contractors have to pay a fee to dump their trucks (Section 4.3 explained in detail the calculation of EV). Furthermore, they are supposed to dispose CDW at official landfills specified by the authority (Hanoi People's Committee) which are limited in number, and are always filled up rather fast. Hence, they have to constantly look for new landfills (private ponds that need backfilling, or abandoned paddy fields...), or have to finally resort to illegal dumping. Should CC-CB is recycled, demolition contractors can sell it to the facility for additional profit while at the same time, they no longer have to worry about dumping sites. Therefore, despite "Cost increase" is ranked first in the list of challenges in implementing classification of CDW, demolition contractors are willing to adopt the ad- 


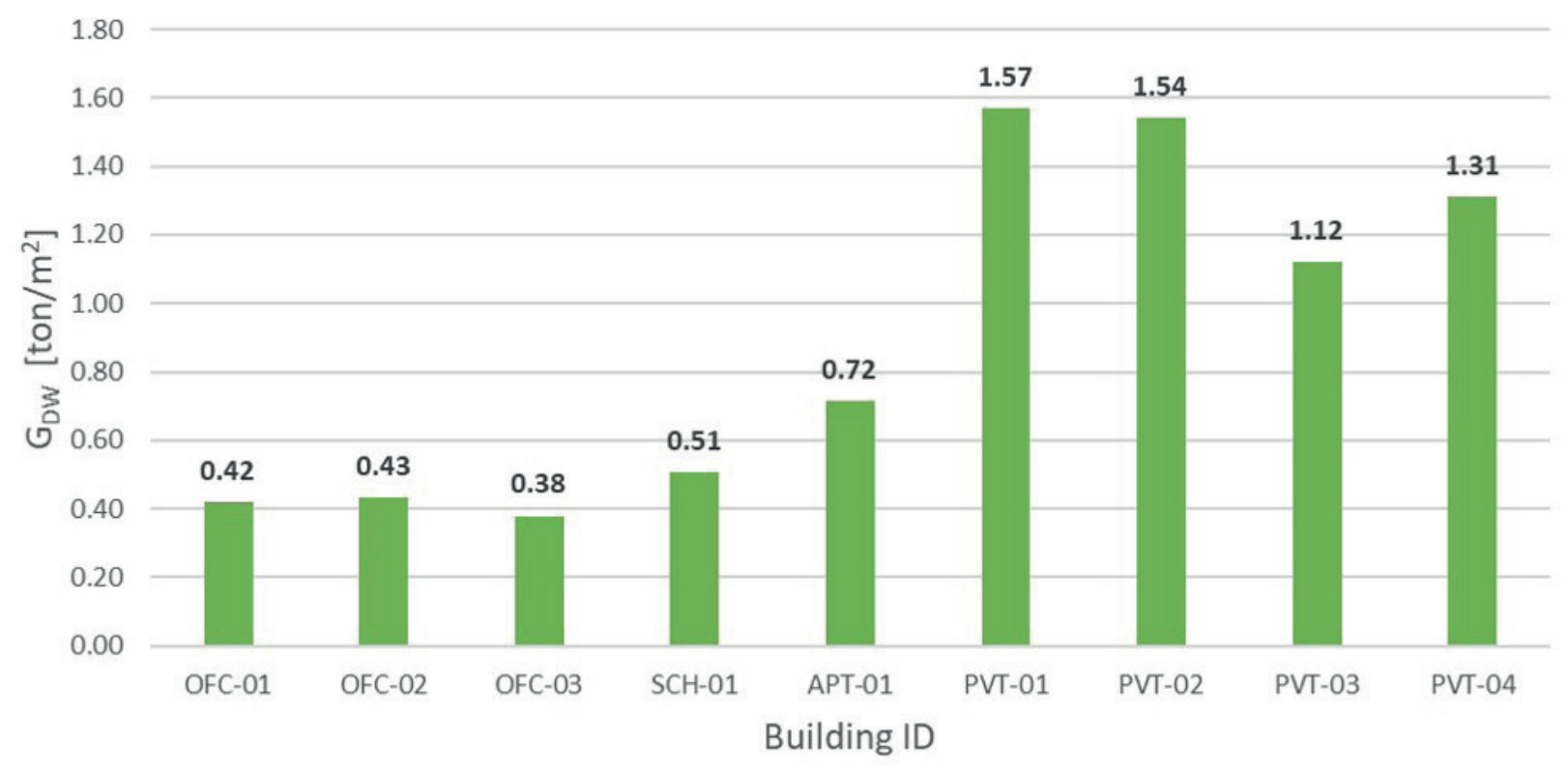

FIGURE 14: Variation of generation rate of DW from surveyed demolition in Hanoi.

ditional process of sorting. This is a concrete evidence to support the opportunites in recycling CDW mentioned in previous studies (Lockrey et al, 2016; Nguyen et al, 2018).

Case study in Hanoi enabled the authors to summarize the typical flow of demolition work, as well as the values of DW generation rate per square meter of GFA for two types of buildings: office and private house. This data could serve as an effective mean to predict the amount of DW generated prior to demolition of buildings of similar types. Combined with the data of new construction available at Departments of Construction of cities (new construction works must be registered with the authority, in which GFA is clearly indicated), it is potentially possible to project a good estimation of DW in the future. This provides an additional approach to the conventional mean of projection by statistical data and growth that are being applied by existing literature.

Compared to a number of neighboring countries, similar studies on the management and generation of CDW, as well as the feasibility of recycling and its economic attractiveness have been conducted much earlier. In China for instance, although dumping CDW at landfills is still the most popular solution due to its simplicity and low cost, it has a potential to cause serious hazards such as the regretable incident in Shenzhen, Southern China in December 2015 where a landslide due to ill-management of dumped CDW resulted in 73 deaths (Yang et al, 2017). Therefore, the central government has been encouraging research on CDW and promoting the recycle of CDW into construction materials (Xiao et al, 2012). It is strongly advisable that Vietnam adopt similar policies and strategies in CDW management in order to minimize the effect of this type of solid waste on the environment.

\section{CONCLUSIONS}

The paper provides insights into the CDW management situation and practices in Vietnam by conducting inter- views with those who are directly involved in such a system - demolition contractors. The investigation first confirmed an alarming increment in the number of demolition works. Secondly, it was revealed that the legislation on CDW in Vietnam is not only lacking, but also ineffective. A feasible procedure to monitor and estimate DW generation was proposed and implemented with nine structures being demolished in Hanoi to quantify the amount of DW. The results yield promising remarks on the relationship between the generation rate and those three factors. Last but not least, data collected from the quantification survey is also crucial in establishing strategies to effectively manage CDW. Future studies may involve strategies for recycling CDW, applications of recycled CDW, feasibility study and business model of producing recycled materials from CDW, expansion of DW generation rate into a thorough study to cover $\mathrm{CW}$ and even more types of structures in Vietnam.

\section{ACKNOWLEDGMENTS}

This research was supported by JST-JICA Science and Technology Research Partnership for Sustainable Development Program (SATREPS) project (No. JPMJSA1701).

\section{REFERENCES}

Banias, G., Achillas, C., Vlachokostas, C., Moussiopoulos, N., Tarsenis, S., 2010. Assessing multiple criteria for the optimal location of a construction and demolition waste management facility. Build. Environ. 45, 2317-2326. https://doi.org/10.1016/j. buildenv.2010.04.016

Bansal, S., Singh, S.K., 2014. A sustainable approach towards the construction and demolition waste. Int. J. Innov. Res. Sci. Eng. Technol. (IJIRSET) 3(2), 9226-9235. https://doi.org/10.15680/ IJIRSET.2015.0411007

Bersgdal, H., Bohne, R.A., Brattebo, H., 2007. Projection of construction and demolition waste in Norwey. J. Ind. Ecol. 11(3), 27-39. https:// doi.org/10.1162/jiec.2007.1149

Coelho, A., de Brito, J., 2012. Influence of construction and demolition waste management on the environmental impact of buildings. Waste Manage. 32, 532-541. https://doi.org/10.1016/j.wasman.2011.11.011 
Coronado, M., Dosal, E., Coz, A., 2011. Estimation of construction and demolition waste (C\&DW) generation and multicriteria analysis of C\&DW management alternatives: A case study in Spain. Waste Biomass Valorization 2, 209-255. https://doi.org/10.1007/ s12649-011-9064-8

de Melo, A.B., Goncalves, A.F., 2011. Construction and demolition waste generation and management in Lisbon (Portugal). Resour. Conserv. Recycl. 55, 1252-1264. https://doi.org/10.1016/j.resconrec.2011.06.010

Deloitte, 2017. Study on Resource Efficient Use of Mixed Wastes, Improving management of construction and demolition waste (Final Report). Prepared for the European Commission, DG ENV.

Deng, X., Liu, G.W., Hao, J.L., 2008. A study of construction and demolition waste in Hong Kong. Proceedings of the 2008 4th International Conference on Wireless Communications, Networking and Mobile Computing, 1-4. Dalian. https://doi.org/10.1109/WiCom.2008.1745

Eurostat, 2018. Waste statistics. Retrieved 17 March 2020 at: https:// ec.europa.eu/eurostat/statistics-explained/index.php/Waste statistics\#Total_waste_generation

Fatta, D., Papadopoulos, A., Avramikos, E., Sgourou, E., Moustakas, K. 2003. Generation and management of construction and demolition waste in Greece - An existing challenge. Resour. Conserv. Recycl. 40, 81-91. https://doi.org/10.1016/S0921-3449(03)00035-1

Hiete, M., Stengel, J., Ludwig, J., Schultmann, F., 2011. Matching construction and demolition waste supply to recycling demand: A regional management chain model. Build. Res. Inf. 39(4), 333-351. https://doi.org/ 10.1080/09613218.2011.576849

Hsiao, T.Y., Huang, Y.T., Yu, Y.H., Wernick, I.K., 2002. Modeling materia flow of waste concrete from construction and demolition wastes in Taiwan. Resour. Policy 28, 39-47. https://doi.org/ 10.1016/ S0301-4207(03)00004-7

Hu, M.M., van der Voet, E., Huppes, G., 2010. Dynamic material flow analysis for strategic construction and demolition waste management in Beijing. J. Ind. Ecol. 14(3), 440-456. https://doi. org/10.1111/j.1530-9290.2010.00245.x

Huang, B., Wang, X., Kua, H., Geng, Y., Bleischwitz, R., Ren, J., 2018. Construction and demolition waste management in China through the 3R principle. Resour. Conserv. Recycl. 129, 36-44. https://doi. org/10.1016/j.resconrec.2017.09.029

Hussin, J.M., Rahman I.A., Memon, A.H., 2013. The way forward in sustainable construction: issues and challenges. Int. J. Advances Appl. 2(1), 15-24. https://doi.org/10.11591/ijaas.v2i1.1321

Jin, R., Li, B., Zhou, T., Wanatowski, D., Piroozfar, P., 2017. An empirical study of perceptions towards construction and demolition waste recycling and reuse in China. Resour. Conserv. Recycl. 126, 86-98. https://doi.org/10.1016/j.resconrec.2017.07.034

Kartam, N., Al-Mutairi, N., Al-Ghusain, I., Al-Humoud, H., 2004. Environmental management of construction and demolition waste in Kuwait. Waste Manage. 24, 1049-1059. https://doi.org/10.1016/j. wasman.2004.06.003

Koforowola, O.F., Gheewala, S.H., 2009. Estimation of construction waste generation and management in Thailand. Waste Manage. 29, 731-738. https://doi.org/10.1016/j.wasman.2008.07.004

Lockrey, S., Nguyen, H., Crossin, E., Verghese, K., 2016. Recycling the construction and demolition waste in Vietnam: Opportunities and challenges in practice. J. Clean. Prod. 133, 757-766. https://doi. org/10.1016/j.jclepro.2016.05.175

Lu, W.S., Yuan, H.P., Li, J.R., Hao, Jane J.L., Mi, X.M., Ding, Z.K., 2011. An empirical investigation of construction and demolition waste generation rates in Shenzhen City, South China. Waste Manage. 31, 680-687. https://doi.org/10.1016/j.wasman.2010.12.004
Luangcharoenrat, C., Intrachooto, S., Peansupap, V., Sutthinarakorn, W., 2019. Factors influencing construction waste generation in building construction: Thailand's perspective. Sustainability 11(13), 3638. https://doi.org/10.3390/su11133638

Mália, M., de Brito, J., Pinheiro, M.D., Bravo, M., 2013. Construction and demolition waste indicators. Waste. Manag. Res. 31(3), 241-255. https://doi.org/10.1177/0734242X12471707

Mercante, I.T., Bovea, M.D., Ibanes-Fores, V., Arena, A.P., 2012. Life cycle assessment of construction and demolition waste management systems: A Spanish case study. Int. J. Life Cycle Ass. 17, 232-241. https://doi.org/10.1007/s11367-011-0350-2

Ministry of Land, Infrastructure, Transport and Tourism (MLIT), 2017. White Paper on Land, Infrastructure, Transport and Tourism in Japan

Ministry of Natural Resources and Environment (MONRE), 2011. 2011 Report on National Environment: Solid Waste

Nguyen, T.K.T., 2009. Hazardous industrial waste management in Vietnam: current status and future directions. J. Mater. Cycles. Waste. Manag. 11, 258-262. https://doi.org/10.1007/s10163-009-0239-3

Nguyen, V.T., Tong, T.K., Dang, T.T.H., Tran, T.V.N., Nguyen. H.G., Nguyen, T.D., Isobe, Y., Ishigaki, T., Kawamoto, K., 2018. Current status of construction and demolition waste management in Vietnam: Challenges and opportunities. Int. J. GEOMATE 15, 23-29. https://doi. org/10.21660/2018.52.7194

Nixon, P.J., 1978. Recycled concrete as an aggregate for concrete A review. Mater. Struct. 11(5), 371-378. https://doi.org/10.1007/ BF02473878

Saez, P.V., del Río Merino, M., Gonzalez, A.S.A., Porras-Amores, C. 2013. Best practice measures assessment for construction and demolition waste management in building constructions. Resour. Conserv. Recycl. 75, 52-62. https://doi.org/10.1016/j.resconrec.2013.03.009

Tam, V.W.Y., 2011. Rate of reusable and recyclable waste in construction. Open Waste Manag. J. 4, 28-32

Tong, T.K., Le, T.T., Phung, V.L., 2013. Recycling construction demolition waste in the world and in Vietnam. Proceedings of the International Conference on Sustainable Environment for Now and the Future, 163-171. Hanoi

United States Environmental Protection Agency (EPA), 2016. Advancing Sustainable Materials Management: 2014 Fact Sheet. Retrieved 17 March 2020 at: https://www.epa.gov/sites/production/ files/2016-11/documents/2014_smmfactsheet_508.pdf

Wu, Z., Yu, A.T.W., Shen, L., Liu, G., 2014. Quantifying construction and demolition waste: An analytical review. Waste Manag. 34, 16831692. https://doi.org/10.1016/j.wasman.2014.05.010

Xiao, J.Z., Li, W.G., Fan, Y.H., Huang, X., 2012. An overview of study on recycled aggregate concrete in China (1996-2011). Constr Build. Mater. 31, 364-383. https://doi.org/10.1016/j.conbuildmat.2011.12.074

Yang, H., Xia, J., Thompson, J.R., Flower, R.J., 2017. Urban construction and demolition waste and landfill failure in Shenzhen, China. Waste. Manag. 63, 393-396. https://doi.org/10.1016/j.wasman.2017.01.026

Zheng, L., Wu, H., Zhang, H., Duan, H., Wang, J., Jiang, W., Dong, B. Liu, G., Zuo, J., Song, Q., 2017. Characterizing the generation and flows of construction and demolition waste in China. Constr. Build. Mater. 136, 405-413. https://doi.org/10.1016/j.conbuildmat.2017.01.055

Zimmermann, H., 2001. Fuzzy Set Theory - and Its Applications (4th ed.). New York: Springer Science+Business Media 